\title{
Aberrant Methylation in Promoters of GSTP1, p16, p14, and RASSF1A Genes in Smokers of North India
}

\author{
Jagdeep S. Deep, ${ }^{1}$ Sukhjeet Sidhu, ${ }^{2}$ Avinash Chandel, ${ }^{1}$ \\ Shruti Thapliyal, ${ }^{1}$ and Charu Garg ${ }^{2}$ \\ ${ }^{1}$ Indian Institute of Science Education and Research (IISER), Sector 81, Mohali 140306, India \\ ${ }^{2}$ SUS College of Engineering and Technology (SUSCET), Tangori, Mohali, India
}

Correspondence should be addressed to Jagdeep S. Deep, jagdeep@iisermohali.ac.in

Received 7 August 2012; Accepted 12 September 2012

Academic Editors: A. Celi and Y. Nishioka

Copyright (C) 2012 Jagdeep S. Deep et al. This is an open access article distributed under the Creative Commons Attribution License, which permits unrestricted use, distribution, and reproduction in any medium, provided the original work is properly cited.

\begin{abstract}
Promoter hypermethylation plays an important role in the inactivation of tumor suppressor/metabolic genes during tumorigenesis. The screening of high-risk population (smokers) for hypermethylation pattern in tumor suppressor/metabolic genes can be a good noninvasive biomarker tool, which should be included in prognosis so that therapeutic measures can be initiated at an early stage. The purpose of this study was to determine the prevalence of aberrant promoter methylation of GSTP1, p16, p14, and RASSF1A genes in smokers and nonsmokers of North India. Our study showed that compared with nonsmokers, smokers have an increased risk of hypermethylation in these genes. We found that $57.3 \%$ of the smokers samples showed methylation for GSTP1, $38 \%$ for $p 16,18 \%$ for $p 14$, and $32 \%$ for RASSF1A. Our population study allowed us to reveal the relationship between smoking and the subsequent appearance of an epigenetic change. Smoking speeds up the hypermethylation of these genes, which are thus unable to express, making the person more susceptible to the risk of lung and other solid carcinomas. Hypermethylation studies on DNA from two lung cancer cell lines (A549 and H460) were also done to compare the results, and the results are similar to samples of smokers.
\end{abstract}

\section{Introduction}

Cancer is neither rare anywhere in the world, nor mainly confined to high-resource countries. The most commonly diagnosed cancers worldwide are lung followed by breast and colorectal cancers. Lung cancer is the most common cause of cancer-related mortality worldwide. About 1,80000 new cases are detected every year $[1,2]$. Because of its high fatality (the ratio of mortality to incidence is 0.86 ) and the lack of variability in survival, in developed and developing countries, the highest and lowest mortality rates are estimated in the same regions, both in men and women. The large number of fatalities illustrates the lack of effective therapeutic alterations for a disease which is mostly diagnosed at an advanced stage [3]. There is a strong need for the development of biomarkers [4-6] that can spot this disease at an early stage which in turn would improve the survival rates. In comparison to mRNA, miRNA, and certain proteins, the use of genomic DNA methylation as biomarker has some novel attractions. Firstly, genomic DNA is highly stable, easy to extract, and secondly it can survive harsh conditions [7]. Genomic DNA has received special attention because of its potential application as a noninvasive, rapid, and sensitive tool which can lead to the development of clinically relevant biomarker for early detection of susceptibility to cancer, prediction of a likely treatment effect, and assessment of tumor response to therapy [8]. The role of methylation in altering gene expression is well established, and this has been detected in both tumor and circulating tumor DNA [9]. Aberrant promoter hypermethylation associated with an epigenetically mediated gene silencing constitutes an alternative to coding regions mutation for loss of gene function in cancer $[10,11]$. The methyl-specific PCR (MSP) protocol designed by Herman et al. [12] is able to assay methylation status of $\mathrm{CpG}$ islands within a gene promoter that correlates with the loss of transcription. 
Recently, several groups have reported that DNA hypermethylation is associated with exposure to tobacco smoke. The promoter methylation of several tumor suppressor genes have been reported in various tumors, including lung cancer, prostate cancer, and colorectal cancers. Among the common targets for aberrant methylation in lung/other solid tumors are the promoter regions of the GSTP1, p14, p16, and RASSF1 genes.

GSTP1, a metabolic gene, plays a key role in detoxification by catalyzing the conjugation of many hydrophobic and electrophilic compounds with reduced glutathione [13]. GST is a group of phase II enzymes that have the ability to regulate the conjugation of carcinogenic compounds to excretable hydrophilic metabolites [14]. The glutathione Stransferase Pi gene (GSTP1) is a polymorphic gene encoding active, functionally different GSTP1 variant proteins that are thought to function in xenobiotic metabolism and play a role in susceptibility to cancer, particularly more in prostate cancer and other diseases [15].

p16 (p16INK4a/CDKN2A), a tumour suppressor gene, is a cell cycle regulator that is frequently inactivated in different types of malignancies, including lung cancer. The gene product of $p 16$ protein is a molecular component of the retinoblastoma protein $(\mathrm{pRB})$ regulatory pathway which inhibits G1 cyclin-dependent kinases [16, 17]. Inactivation of $p 16$ enables phosphorylation of $\mathrm{pRB}$ that releases it from E2F transcription factor and allows progression of cells into $S$ phase $[18,19]$. Suppression of $p 16$ expression has been reported in progression of lung cancer.

p14 gene (p14ARF/ARF) is an alternatively spliced variant of $p 16$ gene encoding a distinct but important regulatory protein functioning in the p53 pathway [20]. Although encoded by the same locus, both proteins act in different cell cycle inhibition pathways. ARF product functions as a stabilizer of the tumor suppressor protein p53, as it can interact with, and sequester, MDM1, a protein responsible for the degradation of p53. This gene is known to be an important tumor suppressor gene. Methylation of $p 14$ promoter has been shown to occur in various human tumours.

RASSF1A (Ras association domain family $1 \mathrm{~A}$ ) gene is a tumor suppressor gene. The encoded protein was found to interact with DNA repair protein XPA. The protein was also shown to inhibit the accumulation of cyclin D1 and thus induce cell cycle arrest. Although the lack of expression of RASSF1A is common in lung cancer, mutations of RASSF1A are rare $[21,22]$. The inactivation of this gene was found to be correlated with the hypermethylation of its CpG-island rich promoter region. Suppression of RASSF1A expression has been reported in progression of lung cancer.

In this study, we want to investigate the prevalence of aberrant promoter methylation of GSTP1, p16, p14, and RASSF1A genes in smokers and nonsmokers of North India.

\section{Materials and Methods}

2.1. Sample Collection. One hundred and fifty blood samples of chronic smokers, with more than 5 cigarettes per day with history of 5 years or more of smoking habit, were collected from different regions of Northern India mainly
Punjab, Haryana, Himachal Pradesh, and New Delhi. Of these smokers, of all males, $40 \%$ consumed alcohol too. As controls, blood was also collected from one hundred and fifty nonsmokers, chosen at random. The blood was collected in EDTA-coated vials and stored at $-80^{\circ} \mathrm{C}$ until DNA was extracted.

2.2. Subject Enrolment. The study was approved by the Institute's Ethics Committee, and all participants gave written informed consent. The subjects were selected randomly; most of them were students/faculty of engineering college and a large number of truck drivers who volunteered to be part of this study. The collection of samples was done by the paramedical staff. A detailed questionnaire designed by Indian Council of Medical Research (ICMR), containing all the information about the family history, age, smoking, drinking, and food habits was duly signed by the subjects at the time of collection of samples.

2.3. Cell Lines and Cell Culture. Human nonsmall cell lung cancer (NSCLC) cell lines H460 and A549 were obtained from NCCS, Pune. H460 cells were maintained in RPMI and A549 in Dulbecco's Modified Eagle Medium (DMEM containing $25 \mathrm{mM}$ glucose) and supplemented with $10 \%$ fetal bovine serum in a humidified incubator at $37^{\circ} \mathrm{C}$ with an atmosphere of $5 \% \mathrm{CO}_{2}$.

2.4. DNA Preparation. Genomic DNA was extracted from cell lines and peripheral blood leukocytes using proteinase$\mathrm{K}$ digestion and phenol/chloroform purification followed by ethanol precipitation. All chemicals were brought from Sigma Aldrich Co.

2.5. From Blood Samples. Briefly, $500 \mu \mathrm{L}$ of blood was taken in a $1.5 \mathrm{~mL}$ eppendorf tube and mixed with $1000 \mu \mathrm{L}$ of RBC Lysis buffer $(0.01 \mathrm{M}$ Tris $\mathrm{HCl}, \mathrm{pH}-7.6,320 \mathrm{mM}$ Sucrose, $5 \mathrm{mM} \mathrm{MgCl}_{2}$, and $1 \%$ Triton $\times 100$ ). Tube was spun at $7000 \mathrm{rpm}$ for 2 minutes. Supernatant was discarded, and steps were repeated three times to remove hemoglobin. Then $400 \mu \mathrm{L}$ of Nucleic acid lysis buffer $(0.01 \mathrm{M}$ Tris $\mathrm{HCl}, 11.4 \mathrm{mM}$ sodium citrate, $1 \mathrm{mM}$ EDTA, $1 \%$ SDS) was added, followed by $100 \mu \mathrm{L}$ of $5 \mathrm{M}$ saturated $\mathrm{NaCl}$ and $600 \mu \mathrm{L}$ of chloroform. Tubes were spun at $7000 \mathrm{rpm}$ for 2 minutes, supernatant was transferred to fresh tube, and $800 \mu \mathrm{L}$ of cold absolute ethanol was added to precipitate DNA. Tubes were mixed gently and then spun at $12000 \mathrm{rpm}$ for 1 minute. Supernatant was discarded and tubes were dried at room temperature for 15 minutes. $30 \mu \mathrm{L}$ of TE buffer, $\mathrm{pH} 8$ was added and tubes were stored at $-20^{\circ} \mathrm{C}$ until use.

2.6. From Cell Lines. DNA was extracted from cell lines using Sigma’s Gen Elute Mammalian Genomic DNA Miniprep Kit (G1N250) as per manufacturer's details.

2.7. DNA Quantification. DNA was quantified using Nanodrop 2000 C (Thermo Fisher Co.) for both blood samples and cell lines. 
2.8. Bisulfite Modification of Genomic DNA. DNA was modified by method described by Clark et al. [23]. Briefly, $2 \mu \mathrm{g}$ of genomic DNA was denatured by adding $2 \mu \mathrm{L}$ of $3 \mathrm{M}$ $\mathrm{NaOH}$. Samples were incubated at $37^{\circ} \mathrm{C}$ for 15 minutes and then at $90^{\circ} \mathrm{C}$ for 2.5 minutes. The tubes were immediately placed in ice so that DNA remains denatured. The tubes were centrifuged at $8000 \mathrm{rpm}$ for 10 seconds to settle DNA. For each reaction, modification mixture was prepared by mixing: denatured DNA $(2 \mu \mathrm{g}), 208 \mu \mathrm{L}$, saturated sodium metabisulphite, $\mathrm{pH}-5$, and $10 \mathrm{mM}$ hydroquinone. Samples were properly mixed and incubated at $55^{\circ} \mathrm{C}$ in water bath for 16 hours.

The modified DNA was then desulfonated and purified using Sigma's Imprint DNA Modification Kit (MOD50) using the prescribed protocol by the manufacturer. The modified DNA was then stored at $-20^{\circ} \mathrm{C}$ until use.

2.9. Methylation-Specific PCR (MS-PCR). MS-PCR was performed using primers specific for methylated and unmethylated DNA for GSTP1, p16, p14, and RASSF1A genes. Primers were designed using Methprimer, a program for designing bisulfite-conversion-based Methylation PCR Primers (http://www.urogene.org/methprimer/indexl.html) [24] from the promoter regions of the four genes whose sequences were retrieved from Transcriptional Regulatory Element Database, TRED (http://rulai.cshl.edu/cgi-bin/ TRED/tred.cgi?process=home) [25]. Details of the primers used in study are given in Table 1 .

Universally methylated DNA (S7821, Chemicon) was used as a positive control for each gene. MS-PCR was performed using Sigma's Jumpstart REDTaq ReadyMix PCR Reaction Mix (R2523). PCRs were carried out in Bio-Rad's MJ Mini Thermal Cycler by using a hot start at $95^{\circ} \mathrm{C}$ for $5 \mathrm{~min}$ and the following cycling parameters: 38 cycles of $95^{\circ} \mathrm{C}$ for $30 \mathrm{~s}, \mathrm{X}^{\circ} \mathrm{C}$ for $45 \mathrm{~s}, 72^{\circ} \mathrm{C}$ for $45 \mathrm{~s}$, and $72^{\circ} \mathrm{C}$ for $10 \mathrm{~min}$, and $4^{\circ} \mathrm{C}$ to cool. After PCR was done, the methylation and unmethylation-specific PCR products were run on $2 \% \mathrm{EtBr}$ agarose gel at $60 \mathrm{~V}$ for 2 hours. The gel was then analyzed using Bio-Rad's Gel Doc XR+ system.

2.10. Statistical Analysis. Statistical analysis was performed using Chi-square test or Fisher's exact test for correlation between smoking and nonsmoking and drinking in combination with smoking in relation to hypermethylation status. All the tests were two sided, and $P<0.05$ was considered statistically significant.

\section{Results}

In the present study, the methylation pattern of GSTP1, p16, p14, and RASSF1A genes was studied in 300 samples, which included 150 smokers, 150 non smokers, and two NSCLC cell lines A549 and H460. Bisulfite conversion and MSP of universal methylated DNA (C. no. S7821, Chemicon) was used as a positive control and universal unmethylated DNA (C. no. S7822, Chemicon) as negative control (Figure 2). The drinking and food preference status of the subjects was also monitored, though the parameter for selection was smoking status only.

Amongst the smokers, 86 subjects out of total 150 showed hypermethylation (57.3\%) in GSTP1, 57 of 150 $(38 \%)$ in $p 16,27$ of $150(18 \%)$ in $p 14$, and 48 of 150 $(32 \%)$ in case of RASSF1A. Even in nonsmokers, 23/150 $(15.3 \%)$ in GSTP1, 18/150 (12\%) in p16, 9/150 (6\%) in p14, and 20/150 (13.3\%) in RASSF1A showed hypermethylation (Figures 1 and 3). Amongst the non smokers, 4 subjects showed hypermethylation in GSTP1 gene, which on further investigation were found to be passive smokers who used to smoke earlier but left smoking 2-3 years ago. Out of the total 150 samples of smokers, 11 samples $(7.3 \%)$ showed hypermethylation of all the four genes and out of these, 9 were drinkers also, but statistically no significant correlation was observed on this count. Our population study allowed us to reveal the relationship between smoking and the subsequent appearance of an epigenetic change. Smoking speeds up the hypermethylation of these genes, $(P=0.0001$ for GSTP1 and $p 16$, Fisher's exact test $)$ and $(P=0.0022$ for p14, $P=0.0002$ for RASSF1A) which are thus unable to express, making the person more susceptible to the risk of lung and other solid carcinomas.

Hypermethylation studies on DNA from two lung cancer cell lines (A549 and H460) were also done to compare the results, and the DNA from both these cell lines showed hypermethylation similar to what was observed in samples of smokers.

\section{Discussion}

The reason for the development of cancer in smokers can be epigenetic changes brought by the chemicals present in tobacco. Tobacco smoke contains numerous carcinogens, including 4-(methylnitrosamino)-1-(3-pyridyl)-1butanone, polyaromatic hydrocarbons, and metals such as chromium, cadmium, and nickel. These chemicals can lead to different epigenetic changes, most specifically changes in DNA methylation machinery. Tobacco smoke is also known to be a source of ROS generation in cells, and this ROS can lead to change in the activities of DNA methyltransferases and thus changes in methylation pattern of a number of genes. In this study, we investigated the association between smoking and the aberrant methylation of $\mathrm{CpG}$ islands at promoter regions of GSTP1, p14, p16, and RASSF1A genes that may play a role in the development of lung cancer and other solid carcinomas.

The results of this study indicate that aberrant promoter hypermethylation of these genes occurs frequently in smokers and passive smokers. These methylation changes persist even after smoking cessation. The results in comparison to controls (nonsmokers), positive control, and two NSCLC cell lines clearly indicate that smoking does change the methylation status of the promoter regions of GSTP1, p16, p14, and RASSF1A genes. Hypermethylation of these genes lead to transcriptional silencing, thus conferring increased risk of lung/other solid tumors. The promoter hypermethylation of these genes leads to epigenetic events that change and make the genetic environment of the transformed cell unstable 
TABLE 1

\begin{tabular}{|c|c|c|c|c|}
\hline Gene & & Annealing temperature $\left({ }^{\circ} \mathrm{C}\right)$ & Primer sequence $\left(5^{\prime}-3^{\prime}\right)$ & Amplicon size \\
\hline$p-14$ & MF & 55 & GTGTTAAAGGGCGGCGTAGC & 141 \\
\hline$p-14$ & MR & 55 & TTTTTGGTGTTAAAGGGTGGTGTAGT & \\
\hline$p-14$ & UF & 55 & AAAACCCTCACTCGCGACGA & 141 \\
\hline$p-14$ & UR & 55 & САСАААААСССТСАСТСАСААСАА & \\
\hline$p-16$ & MF & 56 & TTATTAGAGGGTGGGGCGGATCGC & 151 \\
\hline$p-16$ & MR & 56 & TTATTAGAGGGTGGGGTGGATTGT & \\
\hline$p-16$ & UF & 56 & CCACCTAAATCGACCTCCGACCG & 149 \\
\hline$p-16$ & UR & 56 & ССАССТАААТСААСТСААССТССААССА & \\
\hline RASSF1A & MF & 53 & GTGTTAACGCGTTGCGTATC & 123 \\
\hline RASSF1A & MR & 53 & TTTGGTTGGAGTGTGTTAATGTG & \\
\hline RASSF1A & UF & 53 & AACCCCGCGAACTAAAAACGA & 123 \\
\hline RASSF1A & UR & 53 & САAАССССАСАААСТАAАAАCAA & \\
\hline GSTP1 & MF & 58 & TTCGGGGTGTAGCGGTCGT & 98 \\
\hline GSTP1 & MR & 58 & GATGTTTGGGGTGTAGTGGTTGTT & \\
\hline GSTP1 & MUF & 58 & GCCCCAATACTAAATCACGACG & 108 \\
\hline GSTP1 & UR & 58 & ССАССССААТАСТАААТСАСААСА & \\
\hline
\end{tabular}

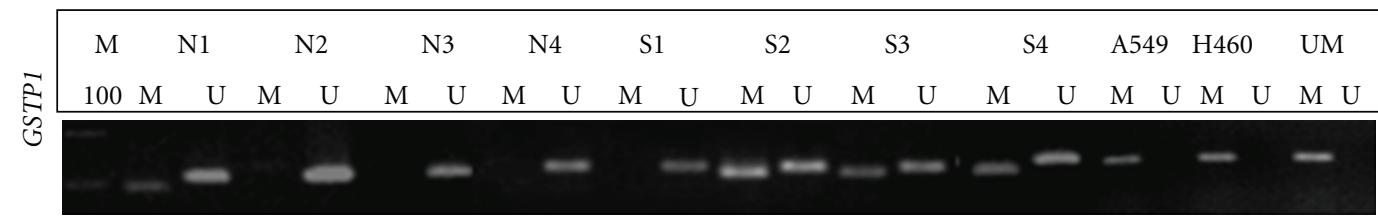

(a)

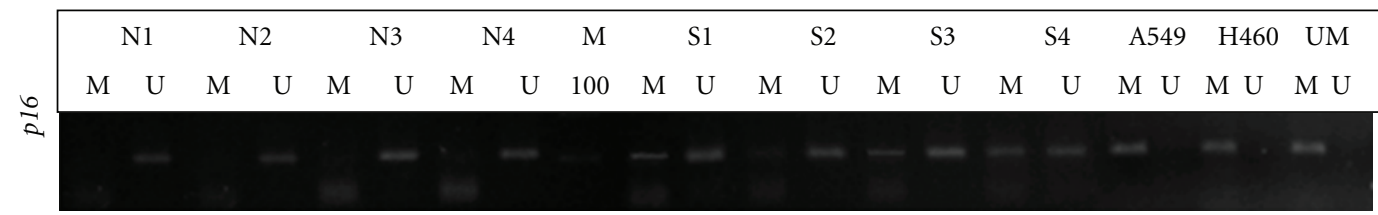

(b)

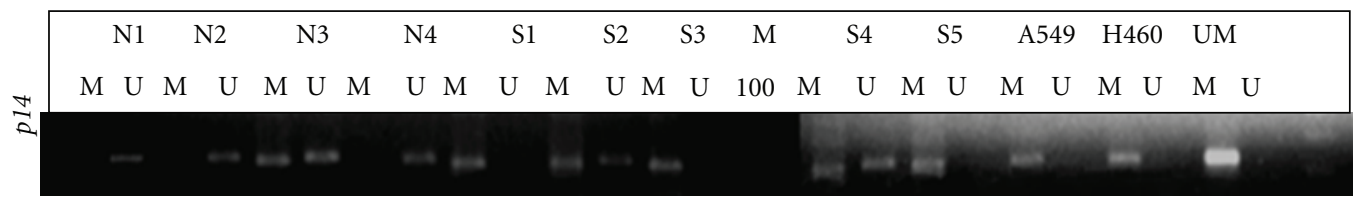

(c)

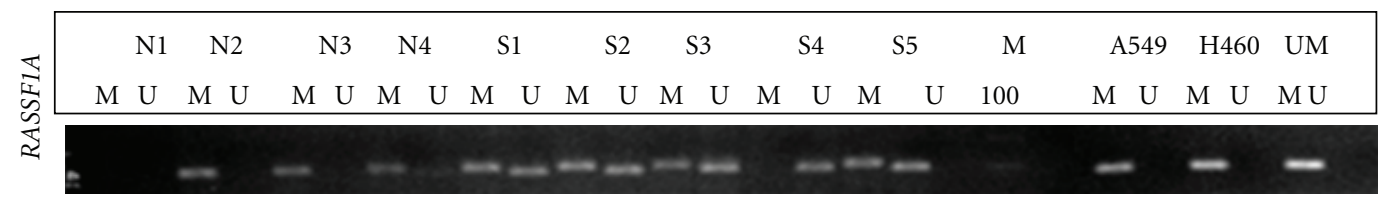

(d)

Figure 1: Methylation analysis of GSTP1, p16, p14, and RASSF1A promoters in nonsmokers (N1, N2, N3, N4), smokers (S1, S2, S3, S4, S5), and NSLC cell lines (A549 and H460). MSP for GSTP1, p16, p14, and RASSF1A was performed using unmethylation-specific (U) and methylation-specific $(M)$ primer sets. Universally methylated DNA (UM) is taken as positive control.

[26]. Although cessation of smoking is associated with a decrease in lung cancer risk, but the prevalence of hypermethylation in these genes in passive smokers after a gap of 2-3 yrs does indicate that the hypermethylation changes once occurred persist for a longer period [27] and does make the subject vulnerable to the risk of lung/other solid tumors. The cumulative risk for lung cancer by age 75 for a person who quits smoking at age 50 is still six times greater than a never-smoker [28]. It is evident from the present study that smoking has a significant contribution towards 
Universally methylated

Universally unmethylated

\begin{tabular}{|c|c|c|c|c|c|c|c|c|c|c|c|c|c|c|c|c|}
\hline \multicolumn{2}{|c|}{ GSTP1 } & \multicolumn{2}{|c|}{ RASSF1A } & \multicolumn{2}{|c|}{ p14 } & \multicolumn{2}{|c|}{ p16 } & $\mathrm{M}$ & \multicolumn{2}{|c|}{$p 16$} & \multicolumn{2}{|c|}{ p14 } & \multicolumn{2}{|c|}{ RASSF1A } & \multicolumn{2}{|c|}{ GSTP1 } \\
\hline $\mathrm{M}$ & $\mathrm{U}$ & $\mathrm{M}$ & $\mathrm{U}$ & $\mathrm{M}$ & $\mathrm{U}$ & $\mathrm{M}$ & $\mathrm{U}$ & 100 & M & $\mathrm{U}$ & $\mathrm{M}$ & $\mathrm{U}$ & $\mathrm{M}$ & $\mathrm{U}$ & M & $\mathrm{U}$ \\
\hline
\end{tabular}

FIGURE 2: Universally methylated and Universally unmethylated DNA as positive and negative controls.

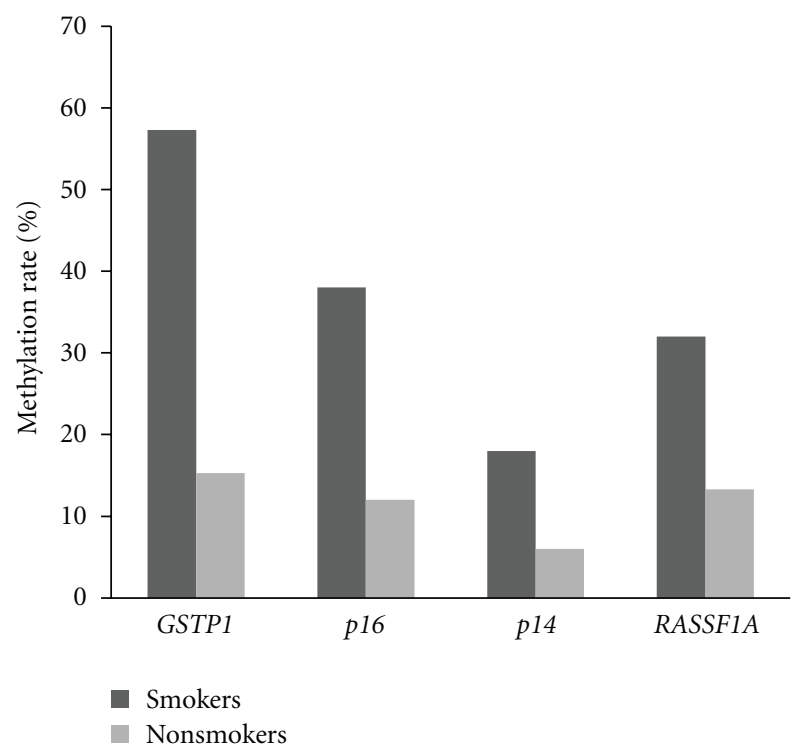

FIGURE 3: Aberrant gene methylation in smokers and nonsmokers. What shown on $y$-axis is the methylation rate percentage of methylation-positive cases (\%) for each of the four genes indicated on the $x$-axis. The methylation rate of the GSTP1, p16 $(P=0.001)$, and RASSF1A $(P=0.002)$ genes is significantly higher in the smokers group than the nonsmoker group. The methylation rate for $p 14$ shows higher trend for smokers but does not reach statistical significance.

hypermethylation of the promoter region of GSTP1, p16, p14, and RASSF1A genes $(P=0.0001,0.0001,0.0022$, and 0.0002 , resp., Fisher's exact test) which increases the risk of developing cancers. This hypermethylation becomes more pronounced with age and drinking accompanied by smoking has a cascade effect in changing the methylation profile of these genes although it is not statistically significant. The study clearly demonstrates that cessation of smoking does not alter the methylation status much and passive smoking is also equally dangerous for changing the methylation status.

The study signifies the importance of continuous investigation of methylation profiling of smokers, where it can become a potential biomarker for the onset of lung cancer/other solid cancers, and an early intervention can save many precious lives. It has been shown that these biomarkers were present in sputum of cancer-free individuals with very high-risk for developing lung tumors [29]. However high frequency of promoter region hypermethylation was observed in $p 16, D A P K$, and MGMT genes in oral cancer tissues as well as in corresponding adjacent normal mucosa [30]. Our previous studies [31-34] have also established the use of aberrant gene methylation as a molecular biomarker system, as a potentially lifesaving approach. Moreover analyzing this from genomic DNA in blood promises a good noninvasive tool for population screening.

\section{Conflict of Interests}

The authors declared they have no conflict of interests.

\section{References}

[1] J. Ferlay, H. R. Shin, F. Bray, D. Forman, C. Mathers, and D. M. Parkin, "Estimates of worldwide burden of cancer in 2008: GLOBOCAN 2008," International Journal of Cancer, vol. 127, no. 12, pp. 2893-2917, 2010.

[2] S. H. Landis, T. Murray, S. Bolden, and P. A. Wingo, "Cancer statistics, 1998," Ca-A Cancer Journal for Clinicians, vol. 51, pp. 15-36, 2001, Erratum appears in Ca-A Cancer Journal for Clinicians, vol. 48, pp. 192, 1998.

[3] G. M. Strauss, R. E. Gleason, and D. J. Sugarbaker, "Screening for lung cancer; another look: a different view," Chest, vol. 113, no. 2, pp. 557-558, 1997.

[4] D. Sidransky, "Emerging molecular markers of cancer," Nature Reviews Cancer, vol. 2, no. 3, pp. 210-219, 2002.

[5] P. W. Laird, "The power and the promise of DNA methylation markers," Nature Reviews Cancer, vol. 3, no. 4, pp. 253-266, 2003.

[6] S. A. Belinsky, K. J. Nikula, W. A. Palmisano et al., "Aberrant methylation of $\mathrm{p} 16^{\mathrm{INK} 4 \mathrm{a}}$ is an early event in lung cancer and a potential biomarker for early diagnosis," Proceedings of the National Academy of Sciences of the United States of America, vol. 95, no. 20, pp. 11891-11896, 1998.

[7] M. J. Duffy, R. Napieralski, J. W. M. Martens et al., "Methylated genes as new cancer biomarkers," European Journal of Cancer, vol. 45, no. 3, pp. 335-346, 2009.

[8] R. E. Board, L. Knight, A. Greystoke et al., "DNA methylation in circulating tumor DNA as a biomarker for cancer," Biomark Insights, vol. 2, pp. 307-319, 2007.

[9] E. Gormally, E. Caboux, P. Vineis, and P. Hainaut, "Circulating free DNA in plasma or serum as biomarker of carcinogenesis: practical aspects and biological significance," Mutation Research, vol. 635, no. 2-3, pp. 105-117, 2007.

[10] J. G. Herman and S. B. Baylin, "Gene silencing in cancer in association with promoter hypermethylation," The New England Journal of Medicine, vol. 349, no. 21, pp. 2042-2054, 2003.

[11] S. B. Baylin, J. G. Herman, J. R. Graff, P. M. Vertino, and J. P. Issa, "Alterations in DNA methylation: a fundamental aspect 
of neoplasia," Advances in Cancer Research, vol. 72, pp. 141196, 1997.

[12] J. G. Herman, J. R. Graff, S. Myöhänen, B. D. Nelkin, and S. B. Baylin, "Methylation-specific PCR: a novel PCR assay for methylation status of CpG islands," Proceedings of the National Academy of Sciences of the United States of America, vol. 93, no. 18, pp. 9821-9826, 1996.

[13] C. S. Morrow, K. H. Cowan, and M. E. Goldsmith, "Structure of the human genomic glutathione S-transferase-p1 gene," Gene, vol. 75, no. 1, pp. 3-11, 1989.

[14] T. R. Rebbeck, "Molecular epidemiology of the human glutathione S-transferase genotypes GSTM1 and GSTT1 in cancer susceptibility," Cancer Epidemiology Biomarkers and Prevention, vol. 6, no. 9, pp. 733-743, 1997.

[15] H. W. Lo, L. Stephenson, X. Cao, M. Milas, R. Pollock, and F. Ali-Osman, "Identification and functional characterization of the human Glutathione S-transferase P1 gene as a novel transcriptional target of the p53 tumor suppressor gene," Molecular Cancer Research, vol. 6, no. 5, pp. 843-850, 2008.

[16] R. A. Kratzke, T. M. Greatens, J. B. Rubins et al., "Rb and p $16^{\text {INK4a }}$ expression in resected non-small cell lung tumors," Cancer Research, vol. 56, no. 15, pp. 3415-3420, 1996.

[17] H. Tanaka, Y. Fujii, H. Hirabayashi et al., "Disruption of the $\mathrm{RB}$ pathway and cell-proliferative activity in non-small-cell lung cancers," International Journal of Cancer, vol. 79, no. 2, pp. 111-115, 1998.

[18] M. Serrano, “The tumor suppressor protein p16 ${ }^{\mathrm{INK} 4 \mathrm{a}}$," Experimental Cell Research, vol. 237, no. 1, pp. 7-13, 1997.

[19] M. Ruas and G. Peters, "The p16 ${ }^{\text {INK4a }} /$ CDKN2A tumor suppressor and its relatives," Biochimica et Biophysica Acta, vol. 1378, no. 2, pp. F115-F177, 1998.

[20] N. E. Sharpless and R. A. Depinho, "The INK4A/ARF locus and its two gene products," Current Opinion in Genetics and Development, vol. 9, no. 1, pp. 22-30, 1999.

[21] R. Dammann, C. Li, J. H. Yoon, P. L. Chin, S. Bates, and G. P. Pfeifer, "Epigenetic inactivation of a RAS association domain family protein from the lung tumour suppressor locus 3p21.3," Nature Genetics, vol. 25, no. 3, pp. 315-319, 2000.

[22] D. G. Burbee, E. Forgacs, S. Zöchbauer-Müller et al., "Epigenetic inactivation of RASSF1A in lung and breast cancers and malignant phenotype suppression," Journal of the National Cancer Institute, vol. 93, no. 9, pp. 691-699, 2001.

[23] S. J. Clark, A. Statham, C. Stirzaker, P. L. Molloy, and M. Frommer, "DNA methylation: bisulphite modification and analysis," Nature Protocols, vol. 1, no. 5, pp. 2353-2364, 2006.

[24] L. C. Li and R. Dahiya, "MethPrimer: designing primers for methylation PCRs," Bioinformatics, vol. 18, no. 11, pp. 1427$1431,2002$.

[25] F. Zhao, Z. Xuan, L. Liu, and M. Q. Zhang, “TRED: a Transcriptional Regulatory Element Database and a platform for in silico gene regulation studies," Nucleic Acids Research, vol. 33, pp. D103-D107, 2005.

[26] M. Esteller, "Epigenetic lesions causing genetic lesions in human cancer: promoter hypermethylation of DNA repair genes," European Journal of Cancer, vol. 36, no. 18, pp. 22942300, 2000.

[27] S. Zöchbauer-Müller, S. Lam, S. Toyooka et al., "Aberrant methylation of multiple genes in the upper aerodigestive tract epithelium of heavy smokers," International Journal of Cancer, vol. 107, no. 4, pp. 612-616, 2003.

[28] R. Peto, S. Darby, H. Deo, P. Silcocks, E. Whitley, and R. Doll, "Smoking, smoking cessation, and lung cancer in the UK since 1950: combination of national statistics with two case-control studies," British Medical Journal, vol. 321, no. 7257, pp. 323329, 2000.

[29] W. A. Palmisano, K. K. Divine, G. Saccomanno et al., "Predicting lung cancer by detecting aberrant promoter methylation in sputum," Cancer Research, vol. 60, no. 21, pp. 5954-5958, 2000.

[30] V. Kulkarni and D. Saranath, "Concurrent hypermethylation of multiple regulatory genes in chewing tobacco associated oral squamous cell carcinomas and adjacent normal tissues," Oral Oncology, vol. 40, no. 2, pp. 145-153, 2004.

[31] J. S. Deep and S. Sidhu, "Methylation pattern of E-cadherin gene as epigenetic biomarker in lung cancer patients," Research Journal of Biotechnology, vol. 3, no. 4, pp. 32-34, 2008.

[32] J. S. Deep and S. Sidhu, "Study of methylation pattern of APC gene as epigenetic biomarker in lung cancer patients," Research Journal of Biotechnology, vol. 3, pp. 435-437, 2008.

[33] J. S. Deep, "DNA methylation: epigenetics to molecular diagnostics," Research Journal of BioTechnology, vol. 4, no. 4, pp. 3-4, 2009.

[34] S. Sidhu, J. S. Deep, R. C. Sobti, V. L. Sharma, and H. Thakur, "Methylation pattern of MGMT gene in relation to age,smoking, drinking and dietary habits as epigenetic biomarker in prostate cancer patients," Genetic Engineering and Biotechnology Journal. In press. 


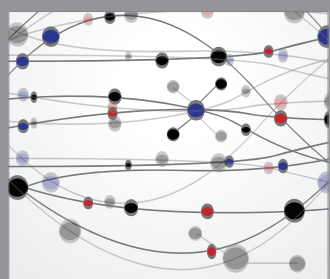

The Scientific World Journal
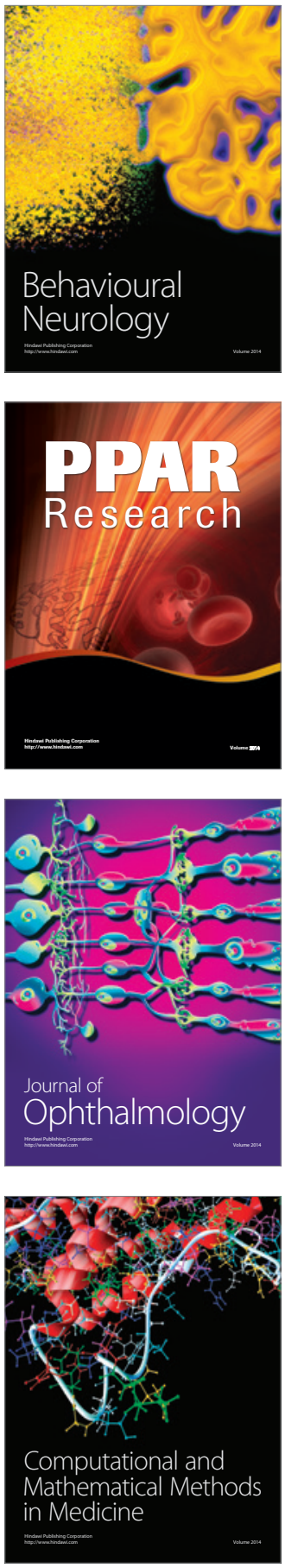

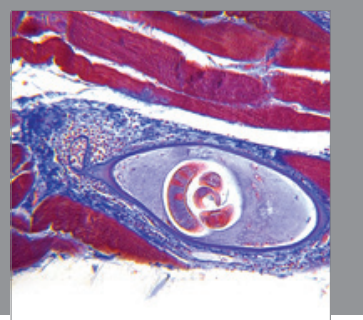

Gastroenterology

Research and Practice
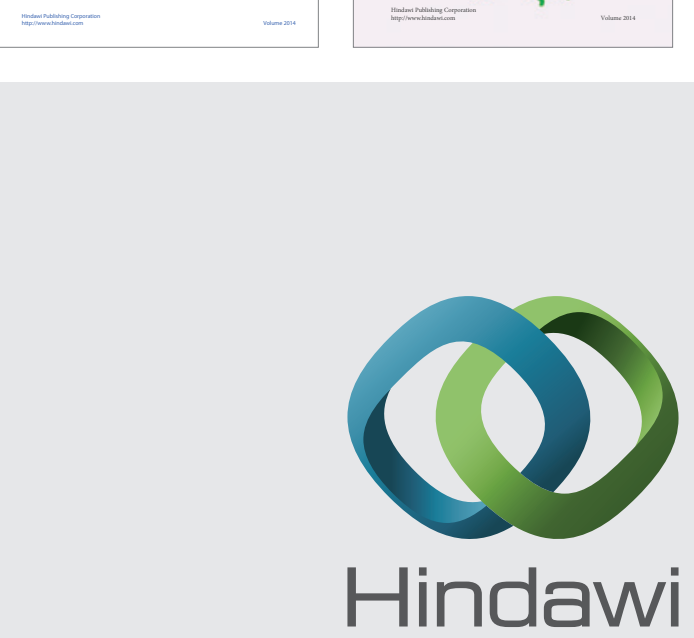

Submit your manuscripts at

http://www.hindawi.com
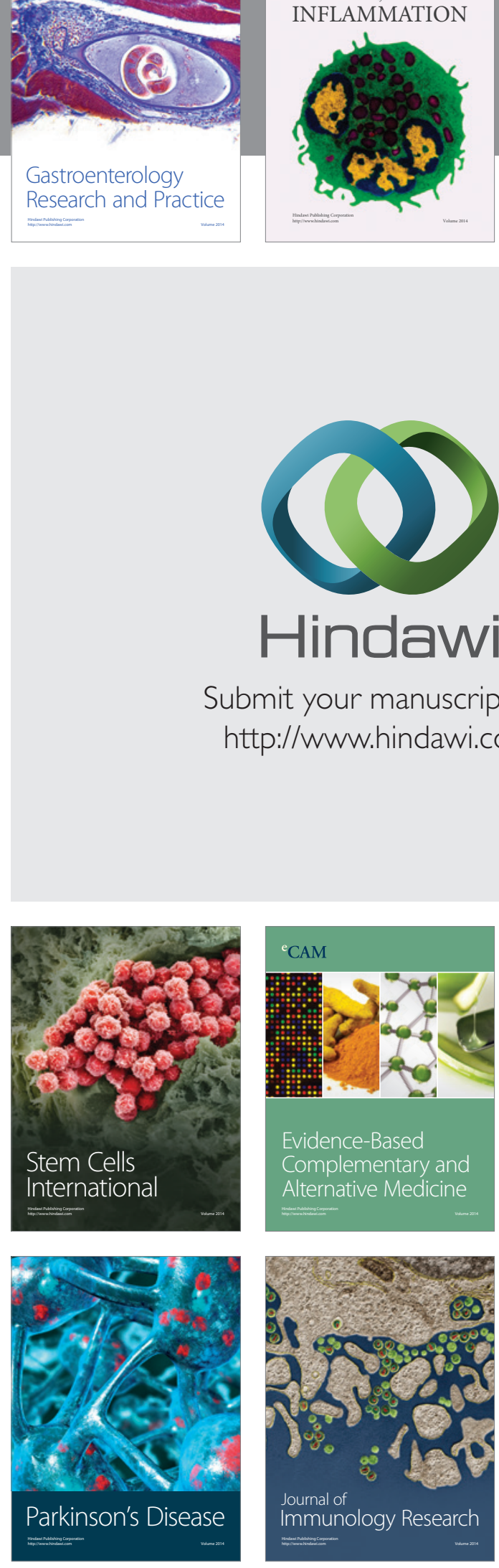

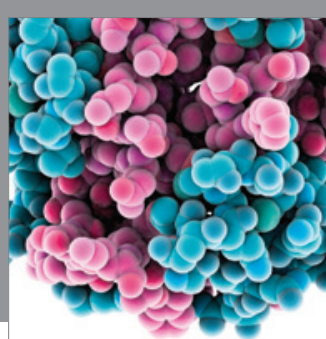

Diabetes Research
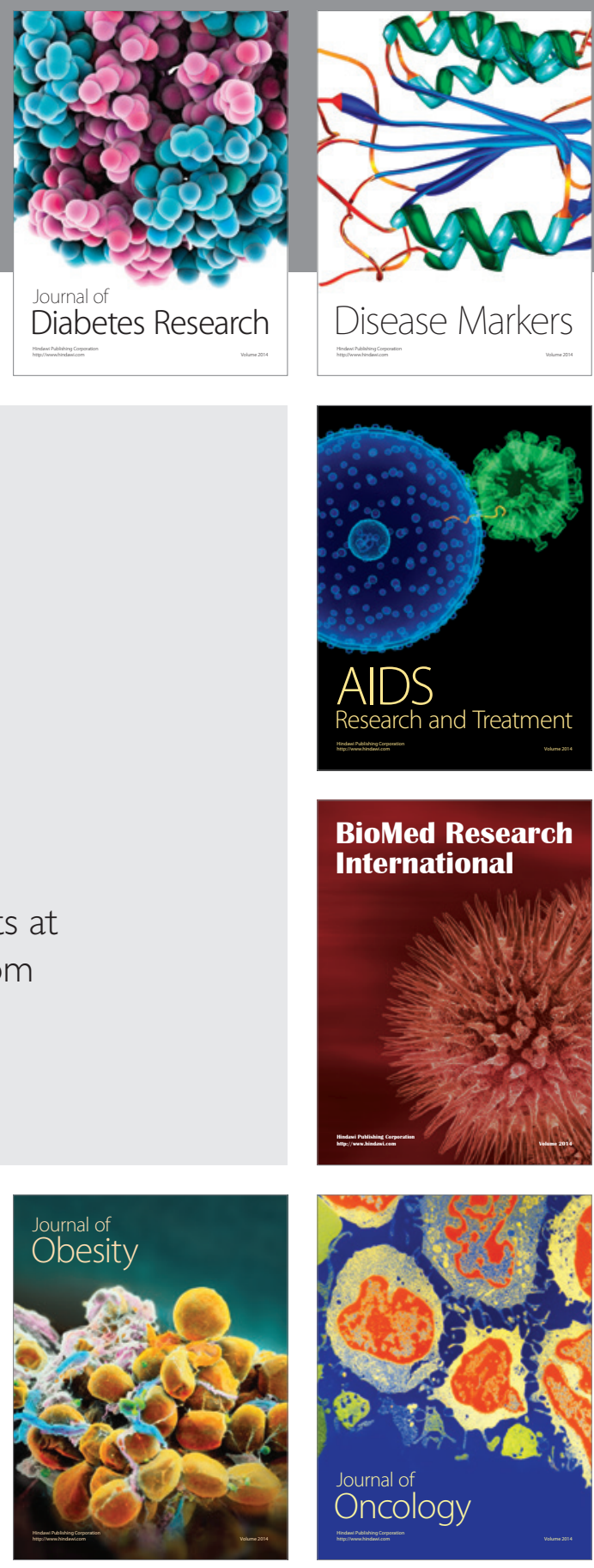

Disease Markers

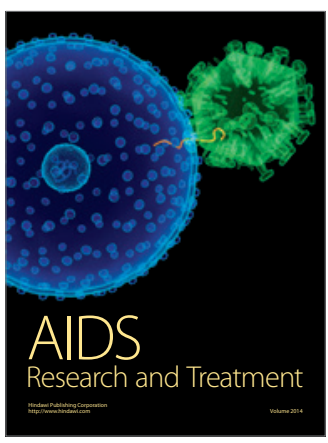

BioMed Research

International
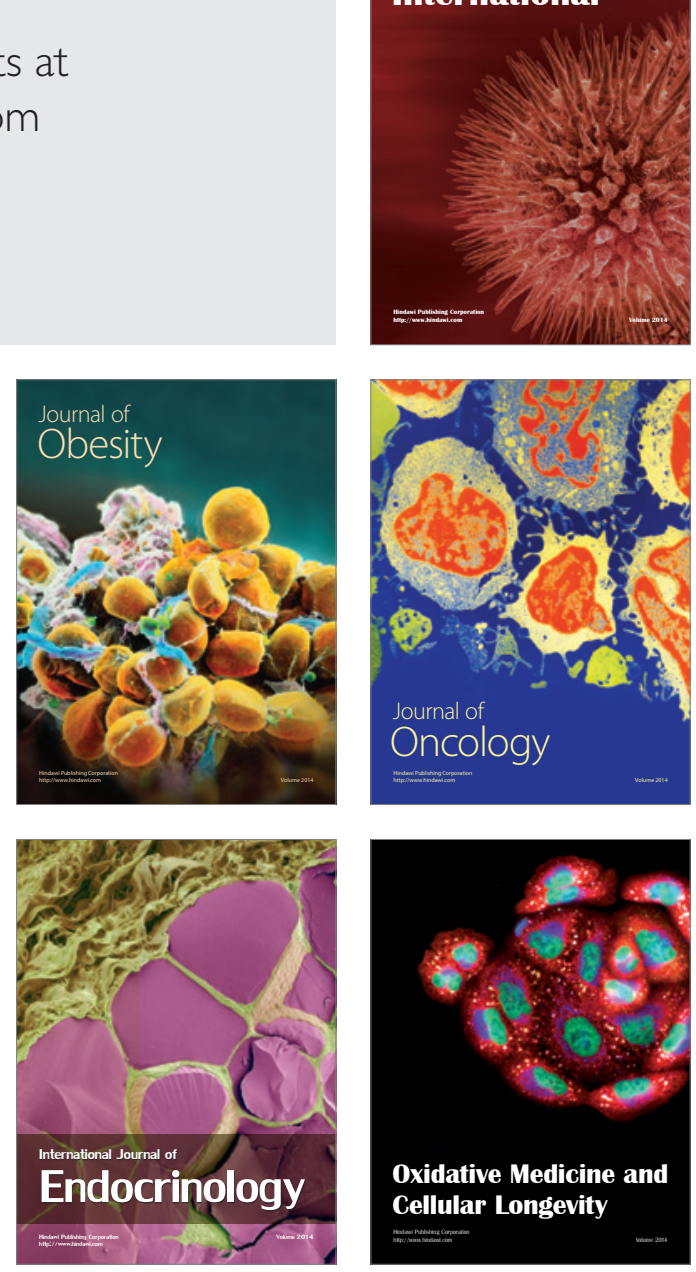